\title{
Think Global—Towards International Consumer Law
}

\author{
Christian Twigg-Flesner • Hans Micklitz
}

Received: 29 April 2010 / Accepted: 3 May 2010 /

Published online: 22 May 2010

(C) Springer Science+Business Media, LLC. 2010

Keywords Transnational consumer law · International consumer law · Services · Goods

This year marks the 25th anniversary of the adoption of the UN Guidelines on Consumer Protection, a document which remains as the only significant contribution to consumer law and policy at the international level. Although there are numerous evolved systems of consumer law around the globe, these have generally emerged either at the national level or within the confines of particular regional associations. Readers of the Journal of Consumer Policy (JCP) will be particularly familiar with the evolution of consumer law within the European Union, a topic which has attracted many contributions. Whilst the Journal of Consumer Policy also features contributions from other areas of the world, these have tended to be focused on particular developments in one country. What we have not seen is a consistent attempt to consider the international implications of consumer law and policy.

At a recent event to launch the Ius Commune Casebook on Consumer Law (Micklitz et al. 2010), Professor Ewoud Hondius, a long-standing expert on consumer law and member of the JCP's Editorial Board, remarked that when he embarked on his career as a legal scholar, consumer law had only been established at the national level - and even there in rudimentary form. There were early signs that consumer law might become of concern to the European level - in 1975, the then member states adopted a famous resolution on consumer policy - and legal scholarship within the European countries has therefore predominantly focused on the development of European Union (EU) consumer law and its impact on the national laws of the member states. But whilst the idea of a consumer law common to the countries who are members of a common market was undoubtedly novel and appealing 35 years ago, times have moved on and consumers are able to buy goods and services from almost anywhere in the world, primarily due to the massive rise of the internet and the opportunities for distance shopping this has created.

C. Twigg-Flesner $(\triangle)$

University of Hull, Law School, Hull HU6 7RX, UK

e-mail: c.twigg-flesner@hull.ac.uk

H. Micklitz $(\bowtie)$

Department of Law, European University Institute, Via Boccaccio 121, 50133 Florence, Italy

e-mail: hans.micklitz@eui.eu 
Legal scholarship, as well as legal developments at the international level, is lagging behind the changes we have witnessed in the way consumers can now acquire goods and services. The challenges posed by the internationalization of consumer transactions have barely been recognized, and have not found the attention of legal scholars on a noticeable scale. The late David Harland was one of the very few who devoted academic attention to the UN Consumer Guidelines (Harland 1987; Harland 1997). Sothi Rachagan edited a collection of essays on the WTO and consumer law, but this was in 1999 (Rachagan 1999). The most serious attempt is the recently published Handbook of Research on International Consumer Law edited by Geraint Howells, Iain Ramsay and Thomas Wilhelmsson (Howells et al. 2010). The time has surely come for legal scholarship to tackle the international issues which arise in more detail, and to develop a concerted effort towards establishing international consumer law as a key component of consumer law scholarship. We, as the JCP's editors responsible for law, wish to use this editorial to fire the starting gun for a process which will place International Consumer Law firmly on the agenda.

\section{The Idea of "International Consumer Law"}

We begin by exploring our conception of "International Consumer Law"-what exactly do we envisage to be the focus of research in this context? There are a number of themes which need to be explored.

First, there will be a strong comparative element: it is necessary to identify the issues which consumers face in different parts of the world and how they have been tackled through the adoption of relevant consumer law measures - are there similarities which could become the focus of mutual learning? For example, if it is discovered that consumers in South America and in Asia are similarly affected by the way goods are advertised to them, a comparative study of the problems and the relevant legal solutions adopted could reveal that very different legislative models can both help to tackle such a problem. Through a comparative study of such approaches, legal scholarship could bring a wider range of solutions to a global audience, and such scholarship could, in turn, shape the development of consumer law elsewhere. It seems to us that at present, there is not nearly enough scholarship in this regard. We acknowledge the very valuable work which is carried out through the International Association of Consumer Law (IACL), which for some years now has hosted a bi-annual international conference on aspects of consumer law with a distinct comparative flavour, but more is needed. Indeed, the IACL might offer a research framework within which to develop the agenda we are setting out in this editorial.

The second aspect is more significant, and is also the area where, in our view, scholarship has been lacking thus far: the international-or, perhaps better, "transnational"- dimension of consumer transactions. Although the paradigm consumer transaction may still be the face-to-face purchase of goods or services from local traders, it has long been possible for consumers to buy goods at a distance; the rise of electronic commerce over the internet has made it possible to buy goods and services from most places around the world. Many e-commerce transactions have a transnational dimension, in that the consumer will be located in a different jurisdiction from that of the trader, and consequently, (at least) two sets of legal rules may come into play. This is, of course, not a new phenomenon, and the rules of private international law, which resolve questions of which courts have jurisdiction to hear a case and of which national law should be applied, have developed to minimize any uncertainty in respect of which rules would apply. However, consumer transactions raise special issues, because in national law, consumer law usually has the character of "mandatory 
law," i.e., it is not possible to displace specific rules adopted for the protection of consumers through the application of a different national law, or terms in a contract seeking to modify or exclude such rules. The existence of various national consumer protection regimes can be a hindrance for both traders and consumers to engage in cross-border transactions.

The third aspect focuses on the comparison of different patterns of regional integration. If at all, research has been focusing on a comparison between the USA and Europe. However, much less attention has been devoted to ongoing tendencies of regional cooperation and regional integration in the two Amercias-NAFTA in the North and MERCOSUR in South America, in Africa (Ohada), in South East Asia (Asean), to name but a few. Whilst it is true that most of these regional integration models are not primarily concerned with consumer law, it is nevertheless worthwhile to study the impact of freetrade agreements on consumer law issues. One might even go one step further and raise the question whether, and to what extent, supranational models which incorporate consumer law might constitute an alternative or at least an intermediate step to international models of legal integration where consumer law might and should play a more promising role.

\section{Potential Fields of Research}

Consumer law cuts across various areas of private and public law. The following is meant to highlight some of the basic issues that might be of interest for in-depth analysis.

The law on consumer sales is such a perennial topic. Readers based in the European Union, in particular, will be aware of the legal response within the EU: over a period of 25 years or so, the EU has adopted a string of measures which seek to harmonize aspects of national consumer laws, to minimize the differences in these mandatory rules and to make cross-border shopping more attractive. More recently, a proposal for a more coherent and extensive measure was put forward which, if adopted, would broaden the harmonized aspects of consumer law. The European solution has therefore been to ensure that the national laws of the member states are sufficiently approximated so as to overcome the potential obstacles posed by national mandatory rules. Crucially, the EU approach does not distinguish between domestic and cross-border transactions. The EU has not attempted to develop a legal framework for cross-border consumer transactions, but rather assumes that through national harmonization, cross-border transactions will be promoted.

However, when it comes to the international level, we find nothing. This contrasts sharply with the field of commercial law, where there are numerous international conventions and other agreements that deal with aspects of transnational commercial law. The most famous of all is the UN Convention on the International Sale of Goods 1980, which has been ratified by over 70 countries. It provides a common legal framework for international sales contracts and deals with the respective rights and obligations of buyers and sellers. Crucially, however, the convention expressly excluded consumer contracts. The more recent UN Convention on the Use of Electronic Communications in International Contracts 2005 similarly excludes consumer contracts from its scope. But why is this so? It seems that consumer law is regarded as a matter for individual jurisdictions, and that agreement at the international level for a common legal framework on consumer protection could not be achieved. It is our contention that this position can no longer be maintained without detailed scrutiny, and that the time has come to challenge this position.

More than $50 \%$ of the gross income in western capitalist democracies results from services. The regulation of consumer services is, however, still at the infant stage. Roughly 
speaking, consumer services cover former public services such as energy, telecommunications, postal services and transport, where statutory incumbents are gradually replaced by private competitors; financial and internet services; as well as all those areas where the service providers are much more bound to a regional or local environment such as construction services, repair services or dry cleaning. The first two categories come under the category of regulated markets, where major players such as the US and Europe set the tone in favour of deregulation and privatization. The governing rules, even if they are formally tied to a regional context, such as the US and Europe, are often agreed upon at the international level. Only the third category still bears a genuine national tone, where national legislators set the standards. Consumer law research in the whole field of services is still underdeveloped. If research exists at all, it is focused on particular regions and, even more, to particular regulated markets, such as transport, energy, or telecommunications. Much needs to be done to settle the rights of consumers in regulated markets, in financial and internet services and even in local or national services.

The list of potential fields of research where knowledge is missing could easily be extended. Advertising and sales promotion is just another empty box. Here, international standards exist: they are developed to a large extent by the International Chamber of Commerce, but this is by far not the only institution. Rules on fair trading which commerce voluntarily subscribes to improve its international image are developed by all sorts of international organizations. Property rights have been extended far beyond traditional boundaries. International organizations are at the forefront of the analysis. They influence the leeway which is left for nation states to guarantee consumers unlimited access to the internet. Health and safety issues equally deserve attention. In the 1990s, the safety of consumer goods, technical goods, pharmaceuticals, chemicals, pesticides played a major role. Today, GMOs should be added to the list. Here, regional rules in the US and the EU prevail over international rules, however, the level of safety is often defined at the international level, by WHO, FAO, CODEX Alimentarius, and UNEP, just to mention the most important ones.

The true challenge today, however, is enforcement. Overstating the point slightly, one might argue that we do not lack rules at the international level, but that we lack appropriate enforcement strategies to ensure that all these rules, often enshrined in nonbinding legal documents, have a practical impact. It is a well-known fact that there are no enforcement authorities at the international level. Early efforts of the UN to set up a body dealing with consumer law issues failed back in the 1980s. That is why international rules have to be enforced by national competent authorities. The legal environment, however, is changing quickly also and in particular with regard to consumer law issues. Arbitration and ADR or on-line dispute resolution mechanisms quickly gain pace to handle transnational consumer complaints. This might be due to the increasing importance of internet sales where borders do not matter anymore. Litigation in and before courts does not really matter in trans-border law issues. It is legally complex, often costly and most of the time inefficient. Collective enforcement is gaining pace, as more and more consumer law issues bear a genuine international dimension. It might suffice to recall the collapse of Lehmann Brothers which concerns millions of consumers world-wide, often under a similar design. The US class action is about to find its European counterpart in collective actions based on opt-in and not opt-out. Whether and to what extent public enforcement authorities could and should have a word to say in private litigation is a highly controversial matter, in particular as there is no agreement on the role and function of public enforcement authorities in consumer law and more particularly in the collective enforcement of consumer law. 


\section{A Global Framework for Consumer Law?}

The development of an International Consumer Law would need to tackle the difficult question of whether it is possible to put into place a global legal framework which could govern all international consumer transactions. There are so many different issues that would have to be considered, and legal scholarship is ideally placed to lay the foundations for such developments. There are a number of initiatives that could be pursued in this regard.

First, an attempt could be made to discover whether there are common principles of consumer law around the world, which could form the basis for an international restatement of consumer law. A model for this approach can be found in the commercial context with the UNIDROIT Principles of International Commercial Contracts. However, such a restatement should not simply be a legal exercise based on comparing national and regional rules and creating from this a common principle; rather, an interdisciplinary approach taking into account research in behavioural economics and consumer psychology would be needed. The purpose of such a restatement of principles would be to serve as a "translation tool" to identify how different legal systems deal with specific consumer protection issues.

Secondly, and again drawing on interdisciplinary research, it will be necessary to identify the specific issues that affect consumers in a transnational context. Many of these, such as language barriers or the cost of shipping goods, cannot be resolved through legislation. However, problems such as what should happen when goods are not delivered, or are faulty, can be dealt with through appropriate legal rules. But whilst one might be able to discover that many legal systems have adopted similar approaches at national level, such a solution might not be appropriate for the transnational level. For example, whilst imposing liability on the person who sold goods to a consumer might work fine in a domestic context, in a transnational setting, a system of producer or network liability might be more appropriate. Substantial research is needed on discovering specifically transnational issues affecting consumers and on identifying appropriate transnational legal solutions. In our view, transnational legal solutions cannot be simply the result of a comparative "best solution" exercise (compare this with the European (Draft) Common Frame of Reference Project, which has primarily been developed through comparative analysis leading to an unarticulated "best solution" statement of rules, with subsequent economic analysis); rather, the starting point should be the problem itself and what would, in practical terms, be the best solution. This, it turn, should lead to appropriate legal rules.

Of course, research into the transnational dimension might reveal that domestic and international issues are similar. If there were to be an international framework for consumer protection, then it would raise the question whether such an effort ought to be restricted to cross-border issues, or-akin to the European approach-whether international activities should lead to a harmonized/uniform consumer law framework for all transactions. Intuitively, it seems to us that the latter approach would stand little chance of success; moreover, we doubt that international uniformity for all consumer transactions is either desirable or acceptable. Domestic variations to respond to domestic concerns should always be possible. However, the particular challenges of transnational consumer transactions merit an international solution. In the vein of the various commercial law instruments agreed at the international level, an international consumer protection framework applicable to cross-border transactions might be the most desirable outcome. 
On the other hand, perhaps the ultimate goal need not be the creation of some sort of international instrument at all. A mature body of research in this field might come to the conclusion that international issues could be tackled in a manner as yet wholly unexplored. Thus, instead of an international framework providing substantial rules of consumer protection, the focus might have to be instead on international dispute resolution for consumer transactions. The best legal framework in the world is no use if those for whose benefit it was created are unable to secure the enforcement of the rights granted to them. It is well known that consumer access to justice is a difficult issue in a domestic context and exacerbated in the regional context. From an international perspective, the challenge will undoubtedly be greater still. Research on these issues is just as sorely needed as on the substantive rules of consumer protection.

Such international developments - be they concerned with enforcement/access to justice or substantive rules - are a long way off, however. First and foremost, comparative research into consumer protection issues around the globe is needed, combined with research into the relevant legal issues. As consumer law scholars, we need to broaden our knowledge base to become much more aware of consumer law around the world, and then to turn to an analysis of the international issues. Furthermore, scholarship from an international perspective may finally help open up under-developed areas of consumer law scholarship, and tackle difficult areas such as the regulation of services more coherently.

Consumer Law scholarship has to evolve to a truly international discipline. Research into domestic consumer law will continue to be relevant - as will be domestic consumer law. However, instead of concentrating on regional developments (such as the continuing development of EU Consumer Law), issues that go beyond a single jurisdiction need an international focus. So the time has come to start to "think global" when it comes to consumer law scholarship.

\section{Next Steps}

So what will be the next steps in the evolution of International Consumer Law and what role will the JCP play in this? More than anything else, we will seek to promote the development of research on International Consumer Law. As editors of the JCP, we invite scholars who are turning towards research into some of the issues we have identified above to consider submitting papers to this journal so we can bring them to a global audience. Furthermore, we plan to organize a conference on the theme "International Consumer Law" in 2011 under the auspices of the JCP to bring together scholars with a view to cementing a research agenda in this area. Of course, this does not mean that JCP will no longer be interested in papers on national and regional developments - quite the opposite is true. In particular, we would welcome papers dealing with areas on which JCP has historically had a more limited coverage. Over time, we hope that the JCP will become a natural home for scholarship on aspects of international consumer law, and we are excited by this prospect.

Hans Micklitz

Christian Twigg-Flesner

\section{References}

Harland, D. (1987). The United Nations guidelines for consumer protection. Journal of Consumer Policy, 10, 245-266. 
Harland, D. (1997). The United Nations guidelines: Their impact in the first decade. In I. Ramsay (Ed.), Consumer law in the global economy (pp. 1-14). Aldershot: Dartmouth.

Howells, G., Ramsay, I., \& Wilhelmsson, T. (Eds.). (2010). Handbook of research on international consumer law. Cheltenham: Edward Elgar.

Micklitz, H., Stuyck, J., \& Terryn, E. (Eds.). (2010). Cases, materials and text on consumer law. Oxford: Hart Publishing.

Rachagan, S. (Ed.). (1999). Consumer protection in the WTO era. Louvain-la-Neuve: AIDC-IACL. 